\title{
Physicochemical Characterization and Papulation Dynamics of Mycoflora in Infected Rhizosphere Soil of Onion White Rot caused by Sclerotium cepivorum
}

\author{
V.R. Kumbhar ${ }^{1}$, S.R. Mane ${ }^{1}$, G.M. Birajdar ${ }^{1}$, S.A. Bansode ${ }^{1}$, \\ C.S. Swami ${ }^{2}$ and U.N. Bhale ${ }^{1}$ *
}

${ }^{1}$ Research Laboratory, Dept of Botany, Arts, Science and Commerce College, Naldurg, Tq. Tuljapur, Osmanabad 413602, Maharashtra, India

${ }^{2}$ Dept of Botany, Dayanand Science College Latur-413512, India

*Corresponding author

\section{A B S T R A C T}

\section{Keywords}

Mycoflora, Rhizosphere, Onion and Sclerotium cepivorum

Article Info

Accepted:

20 July 2018

Available Online:

10 August 2018
The present study describes physicochemical characterization and rhizosphere soil mycoflora in the field of onion white rot caused by Sclerotium cepivorum. Soil fungi in onion infected field need to improve knowledge of diversity of fungi associated with white rot of onion. Infected rhizosphere soil, sixteen physicochemical parameters were analysed. It founds alkaline $\mathrm{pH}$ but $\mathrm{EC}, \mathrm{N}, \mathrm{Ca}, \mathrm{Na}, \mathrm{B}, \mathrm{S}$ and $\mathrm{Mo}$ contents were found least whereas $\mathrm{OC}, \mathrm{P}, \mathrm{K}, \mathrm{Zn}$ and $\mathrm{Cu}$ high in infected soil as compared to standard range. Due to infected soil, chemical analysis is also hanged. Fifteen samples of soil were carried out during June- Sept and Dec-Feb 2017. In all the 09 genera and 10 species were observed from infected soil. Mucor, Rhizopus and Aspergillus species were found dominant. Total number of fungal species colony was found dominant in Osmanabad (OD) site. Parentage of frequency and \% of abundance was found more in Rhizopus stolonifer (80\% and $15.39 \%$ ) respectively.

\section{Introduction}

Onion (Allium cepa L.) is an important vegetable for potential foreign exchange earners for a country like India, as it is second largest producer of onions after China, producing 1.6 million MT annually FAO (2012). It is also known as "queen of kitchen". Productivity of onion is affected by many biotic and abiotic stresses especially diseases. The onion producing states in India includes mainly, Maharashtra, Karnataka, Gujrat, Bihar and Madhya Pradesh, among these state Maharashtra is contributed $32.6 \%$ of the total production (Anonymous, 2009). The soil microbes decompose the plant and animal residues entering the soil and convert them into soil organic matter, which influences on soil physical, chemical and biological properties and on creating a complimentary medium for biological reactions and life support in the soil environment. Never the less enhanced site-specific diversity typically results in higher levels of below ground 
microbial diversity and production. Large quantities of readily decomposable organic matter are added to agricultural soils every year as crop residues or animal wastes and have a significant outcome on soil microbial population. The physicochemical study of parameters is important to agriculturist for plants growth and soil management. The plant species growing on the soil also equally influence the population and species composition of the soil fungi along with infected pathogen. Some studies dealt with the influence of plant community and others attempted to examine seasonal trends (Kennedy et al., 2005). Soil mycoflora plays a pivotal role in evaluation of soil conditions and in stimulating plant growth (Singh et al., 1999) by biochemical transformation and mineralization activities in soils. The soil is a complex organization being made up of inorganic matter, organic matter, soil organisms, soil moisture, soil solution and soil air and soil contains 50-60\% mineral matter, $25-35 \%$ water, $15-25 \%$ air and little percentage of organic matter (Chatwal et al., 2005). Other non-point sources of contamination affecting agricultural soils include inputs such as, fertilizers, pesticides, sewage sludge and organic (Singh, 2001). Shamir and Steinberger (2007) reported that the topsoil contains high organic matter, which in the presence of adequate moisture supply, acted upon by the microorganisms to decompose the complex organic residues into simpler forms; hence, microbial populations are generally higher in the surface soil layer as compared to the lower depths. Higher fungal population during rainy and autumn season supported the findings of other workers (Arunachalam et al., 1997), due to prevailing favorable moisture and temperature condition. Therefore the objective of the present study was to find the physiological changes and population of mycoflora due to white rot of onion caused by Sclerotium cepivorum.

\section{Materials and Methods}

\section{Physico-chemical characterization}

Physico-chemical analysis of infected rhizosphere soil were collected from study area and used for physicochemical characterization. Soil were spread out on a tray for air drying and sieved over a $150 \mathrm{~mm}$ and used for characterization. Each sample is weighed using digital balance. The samples were then oven-dried at a temperature of $110^{\circ} \mathrm{C}$ for 24 hours and reweighed. Electrical conductivity and $\mathrm{pH}$ of compost were measured (Subbiah and Asija, 1956). Nitrogen content was determined by the Kjeldahl method (Sahilemedhin and Bekele, 2000). Organic Carbon was evaluated (Walkely and Black, 1934) method by oxidizing organic carbon with potassium dichromate and sulphuric acid.

Phosphorus in soil was determined by Olsens method by using spectrophotometer (Olsen et al., 1954; Bray and Kurtz, 1945). Water soluble and exchangeable Potassium was calculated by Ammonium acetate method (Hanway and Heidel, 1952) using Flame photometer. Sodium, Calcium and Magnesium cations were estimated by EDTA titration (GOI, 2011). Analysis of Ferrous, Manganese, Copper, Boron, Sulphur, Zinc and Molybdenum were done by acid digestion of soil (Jackson, 1967).

\section{Population dynamics of mycoflora}

\section{Infected rhizosphere soil collection sites}

Isolation of fungi from infected rhizosphere soil of onion white rot caused by Sclerotium cepivorum from different localities viz. NDNanded, LT-Latur, OD-Osmanabad, SRSolapur, BD-Beed, AD-Aurangabad, TRTuljapur, LA-Lohara, MM-Murum, OAOmerga, UR- Udgir, PR-Pandharpur. SA- 
Sangola, MA-Mangalweda and NG-Naldurg was carried out.

\section{Isolation of fungi by dilution plating method}

For the isolation of mycoflora, dilution plate method was employed (Apinis, 1963; Warcup (1950). Ten grams of sample were transferred to a flask containing $100 \mathrm{ml}$ sterile water. The contents were crushed and shaken on a mechanical centrifuge for $15 \mathrm{~min}$ and then serially diluted to obtain $10^{-3}$ andof $0.5 \mathrm{ml}$ of each was transferred to sterile petri plates containing potato dextrose agar (PDA) medium.

The $\mathrm{pH}$ of medium was adjusted by adding $0.1 \mathrm{~N} \mathrm{HCl}$ or $0.1 \mathrm{~N} \mathrm{NaOH}$. Petri plates were incubated in an inverted position at $27 \pm 2^{0} \mathrm{C}$ in dark.

\section{Identification of fungi}

Fungal morphology were studied macroscopically by observing colony features (Colour and Texture) and microscopically by staining with lacto phenol cotton blue and observe under compound microscope for the conidia, conidiophores and arrangement of spores (Aneja, 2001). The fungi were identified with the help of literature (Nagamani et al., 2006; Ellis, 1976; Ainsworth et al., 1973). The percentage of incidence, frequency and abundance were calculated by employing the following formulae (Girisham et al., 1986).

$$
\begin{aligned}
& \text { No of colonies of species in all plates } \\
& \% \text { of incidence }=\frac{\text { Total no of colony of the all the species in all plates }}{\mathrm{X}} 100 \\
& \text { No of observation in which species appeared } \\
& \begin{array}{ll}
\% \text { of frequency }= & \text { X } 100
\end{array} \\
& \text { Total no of observations } \\
& \text { No of colonies of species in all observations } \\
& \% \text { of abundance }=\frac{\text { Total no of colonies in all observations }}{\times 100}
\end{aligned}
$$

\section{Statistical analysis}

The number of colonies per plate in $1 \mathrm{~g}$ of soil was calculated and the percent contribution of each isolated fungi were determined. Data were statistically analysed and the significance of differences was determined by using book (Mungikar, 1997).

\section{Results and Discussion}

\section{Physico-chemical characterization}

Infected rhizosphere soil was collected from white rot of onion and sixteen physicochemical parameters were analysed. It founds alkaline $\mathrm{pH}$ but $\mathrm{EC}, \mathrm{N}, \mathrm{Ca}, \mathrm{Na}, \mathrm{B}, \mathrm{S}$ and Mo contents were found least whereas $\mathrm{OC}, \mathrm{P}, \mathrm{K}, \mathrm{Zn}$ and $\mathrm{Cu}$ high in infected soil as compared to standard range. Due to infected soil, chemical analysis is also changed. Among 16 characterization, Phosphorus $(467 \pm 12.11 \mathrm{~kg} / \mathrm{ha})$ and Potassium $(526.8 \pm 11.22 \mathrm{~kg} / \mathrm{ha})$ contents was found very high as compared to standards. In case of Nitrogen $\quad(94.05 \pm 3.22 \mathrm{~kg} / \mathrm{ha}), \quad$ Calcium $(4.68 \pm 1.33 \mathrm{mg} / \mathrm{kg})$ and Sodium $(1.69 \pm 3.33 \mathrm{mg} / \mathrm{kg})$ was found very poor support in infected soil (Table 1). 


\section{Population dynamics of mycoflora}

Fifteen samples of infected rhizosphere soil (surface of $0-5 \mathrm{~cm}$ deep) from different localities were collected during pre and postharvest infection of onion and carried out for isolation, quantification and identification of microflora by dilution plate technique. In all the 09 genera and 10 species viz. Mucor muиdo, Aspergillus niger, Aspergillus flavus, Rhizopus stolonifera, Fusarium oxysporum, Pythium sp, Trichoderma harzianum, Rhizoctonia solani, Cladosporium spand Penicillium chrysogenum were observed. Mucor, Rhizopus and Aspergillus species were found dominant. Total number of fungal species colony was found dominant in Osmanabad (OD) site. Parentage of frequency and $\%$ of abundance was found more in Rhizopus stolonifer (80\% and 15.39\%) respectively (Table 2; Fig. 1 and 2). It observed from finding that when more population dynamics of mycoflora shows less white rot of onion infection by Sclerotium cepivorum. Graphical representation of percent contribution of fungal species in infected onion fields was showed in figure 3 .

Organic matters acts as glue for binding soil components and improve water infiltration and water holding capacity and organic carbon or organic matter is the indicator of soil quality and productivity (Fawcett and Caruana, 2001). Chaudhari (2013) studied that the physicochemical study of soil is based on various parameters like total Organic Carbon, Nitrogen $(\mathrm{N})$, Phosphorus $\left(\mathrm{P}_{2} \mathrm{O}_{5}\right)$, Potassium $\left(\mathrm{K}_{2} \mathrm{O}\right), \mathrm{pH}$ and Conductivity and results showed that all the eight selected places of Bhusawal have medium or high mineral content.

Table.1 Physico-chemical characters of infected soil of onion white rot caused by Sclerotium cepivorum

\begin{tabular}{|c|c|c|c|}
\hline $\begin{array}{l}\text { Sr. } \\
\text { No }\end{array}$ & Parameters & $\begin{array}{l}\text { Standard } \\
\text { Range }\end{array}$ & $\begin{array}{l}\text { Infected soil } \\
( \pm S E)\end{array}$ \\
\hline 1 & $\mathrm{pH}$ & 6.5 to 7.5 & $7.6 \pm 0.99$ \\
\hline 2 & Ele. Conductivity ${ }^{3} \mathrm{mS}$ & Less than 1.0 & $0.15 \pm 0.11$ \\
\hline 3 & Organic carbon \% & 0.41 to 0.60 & $1.86 \pm 0.11$ \\
\hline 4 & Nitrogen ${ }^{3} \mathrm{~kg} / \mathrm{ha}$ & 161 to 320 & $94.05 \pm 3.22$ \\
\hline 5 & Phosphorus ${ }^{3} \mathrm{~kg} / \mathrm{ha}$ & 31 to 50 & $467 \pm 12.11$ \\
\hline 6 & Potassium ${ }^{3} \mathrm{~kg} / \mathrm{ha}$ & 181 to 240 & $526.8 \pm 11.22$ \\
\hline 7 & Calcium ( mg/kg) & 65 to 80 & $4.68 \pm 1.33$ \\
\hline 8 & Magnesium ( mg/kg.) & 10 to 15 & $12.32 \pm 2.66$ \\
\hline 9 & Sodium ( $\mathrm{mg} / \mathrm{kg}$ ) & 5 to 15 & $1.69 \pm 3.33$ \\
\hline 10 & Zinc (ppm ) & 1.0 to 5.0 & $4.99 \pm 1.11$ \\
\hline 11 & Ferrous (ppm ) & 2.5 to 5.0 & $3.35 \pm 1.01$ \\
\hline 12 & Manganese (ppm ) & 2.0 to 5.0 & $3.74 \pm 1.13$ \\
\hline 13 & Copper (ppm ) & 0.2 to 0.5 & $2.83 \pm 0.10$ \\
\hline 14 & Boron ( mg/gm ) & 30 to 100 & $23 \pm 2.55$ \\
\hline 15 & Sulphur (mg/kg) & 10 to 20 & $09 \pm 2.32$ \\
\hline 16 & Molybdenum(mg/kg) & 0.8 to3.3 & $0.43 \pm 0.34$ \\
\hline
\end{tabular}

Values are Mean \pm Standard Error 
Table.2 Population dynamics of mycoflora in infected rhizosphere soil of onion white rot caused by Sclerotium cepivorum

\begin{tabular}{|c|c|c|c|c|c|c|c|c|c|c|c|c|c|c|c|c|c|c|c|}
\hline \multirow{2}{*}{$\begin{array}{l}\mathrm{Sr} \\
\text { No }\end{array}$} & \multirow[t]{2}{*}{ Fungi } & \multicolumn{18}{|c|}{ Sclerotium cepivorum infected soil samples sites } \\
\hline & & ND & $\mathbf{L T}$ & OD & SR & BD & AD & TR & LA & MM & OA & UR & PR & $\mathbf{S A}$ & MA & NG & TS & PF & PA \\
\hline 1 & Mucor muudo & + & - & + & + & + & + & - & + & + & - & + & + & + & + & - & 11 & 73.33 & 14.11 \\
\hline 2 & Aspergillus niger & + & + & + & + & - & - & + & + & - & + & + & + & + & - & - & 10 & 66.67 & 12.83 \\
\hline 3 & Aspergillus flavus & - & + & + & + & - & - & - & + & + & + & + & + & + & + & + & 11 & 73.33 & 14.11 \\
\hline 4 & Rhizopus stolonifer & + & + & + & - & + & + & + & - & + & + & - & + & + & + & + & 12 & 80.00 & 15.39 \\
\hline 5 & Fusarium oxysporum & - & + & - & + & - & + & - & + & - & + & + & + & + & + & - & 9 & 60.00 & 11.54 \\
\hline 7 & Trichoderma harzianum & - & - & + & - & - & - & + & - & - & + & + & - & - & - & + & 5 & 33.34 & 6.42 \\
\hline 8 & Rhizoctonia solani & - & - & + & - & - & + & - & + & - & - & - & - & - & - & - & 3 & 20.00 & 3.85 \\
\hline 9 & Cladosporium sp & - & - & + & - & - & + & + & - & - & + & - & - & - & - & + & 5 & 33.34 & 6.42 \\
\hline 10 & Penicillium chrysogenum & - & + & - & + & + & - & - & - & - & - & - & + & + & - & + & 6 & 40.00 & 7.70 \\
\hline \multicolumn{2}{|c|}{ Total No. of colonies } & 4 & 5 & 8 & 5 & 3 & 5 & 5 & 5 & 4 & 6 & 6 & 6 & 6 & 4 & 6 & \multirow[t]{2}{*}{78} & & \\
\hline \multicolumn{2}{|c|}{$\%$ Incidence } & 5.13 & 5.13 & 10.26 & 5.13 & 3.85 & 5.13 & 5.13 & 5.13 & 5.13 & 7.70 & 7.70 & 7.70 & 7.70 & 5.13 & 7.70 & & & \\
\hline
\end{tabular}

Legands:ND-Nanded,LT-Latur,OD-Osmanabad,SR-Solapur,BD-Beed,AD-Aurangabad.TR-Tuljapur, LA-Lohara, MM-Murum, OA-Omerga, UR- Udgir,PRPandharpur.SA-Sangola,MA-Mangalweda,NG-Naldurg,TS-Total Species, PI-Percentage Incidence, PF- Percentage Frequency, PA- Percentage Abundance 
Fig.1
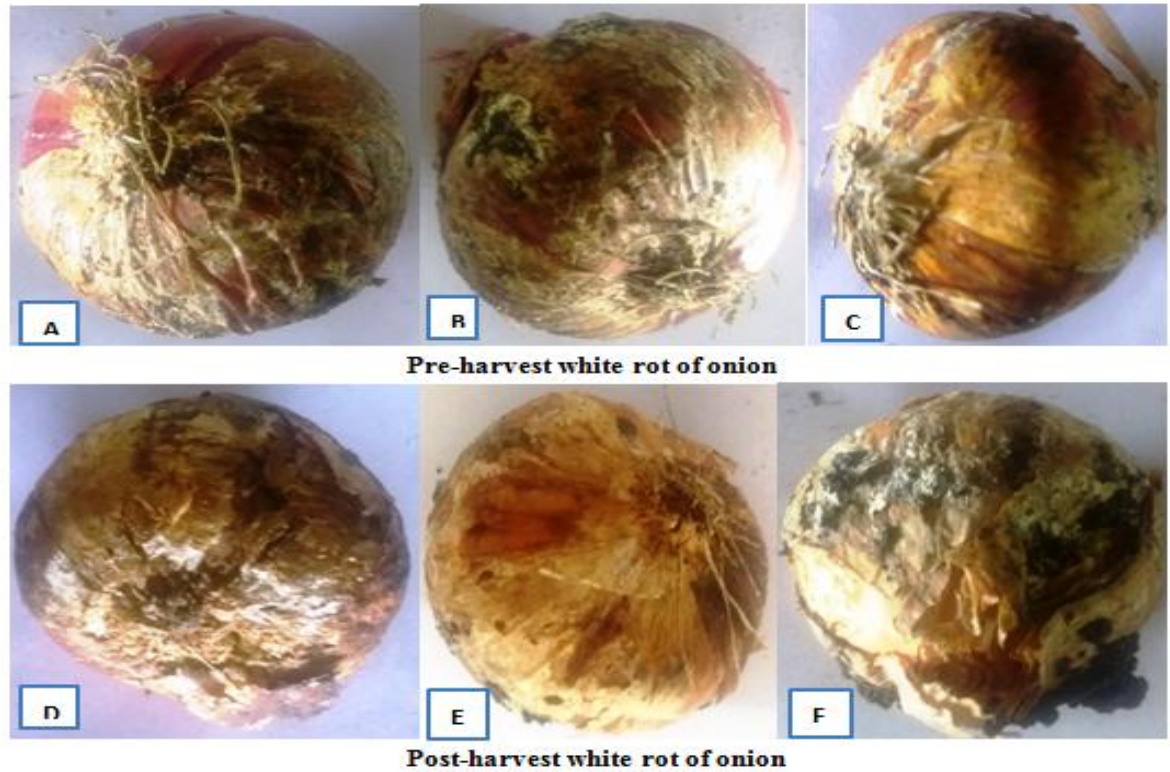

Fig.1. Pre and post-harvest white rot infection of onion bulb caused by Sclerotium cepivorum.

Fig.2
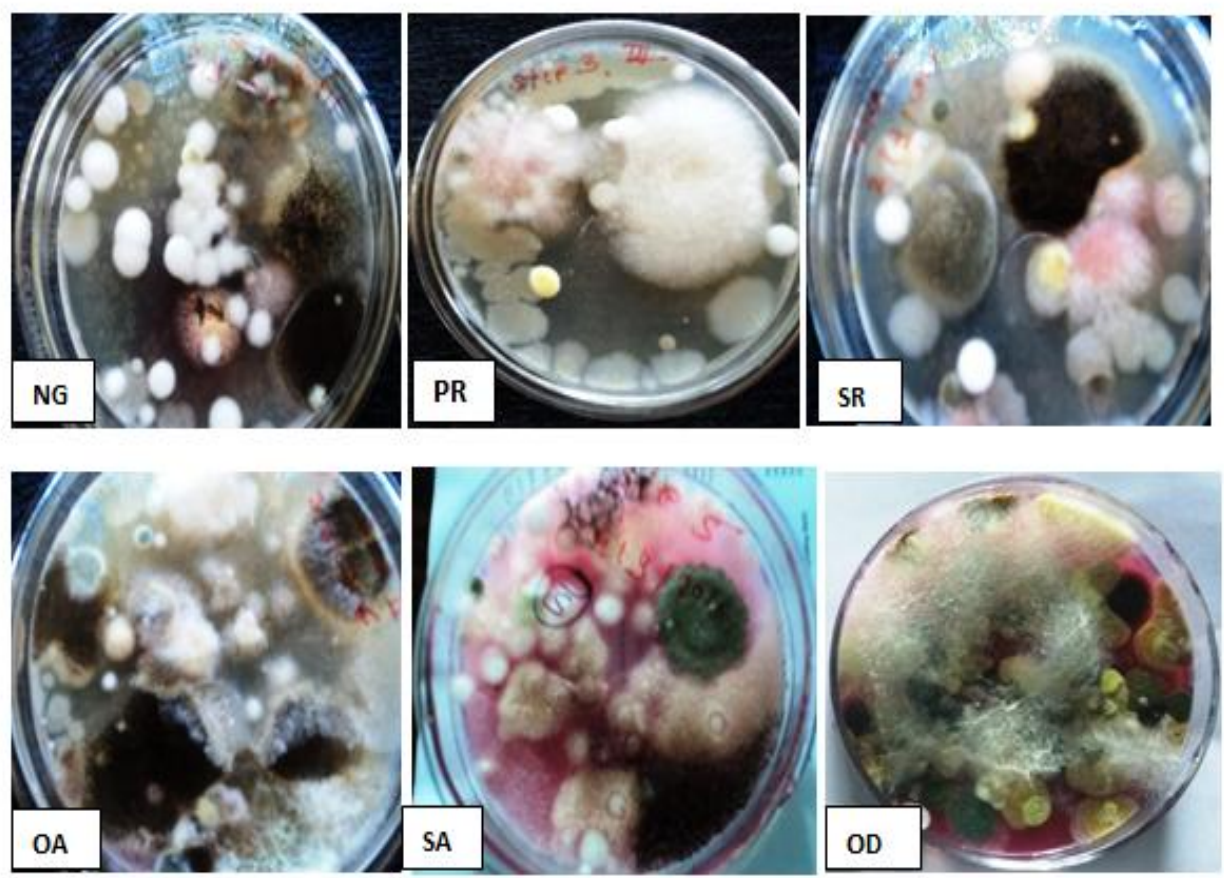

Fig.2. Dominant fungsal colony in infected rhizosphere soil of onion white rot caused by Sclerotium cepivorum from different localities (NG- Naldurg, PR-Pandharpur, SR-Solapur, OA-Omerga, SA-Sangola , ODOsmanabad). 
Fig.3

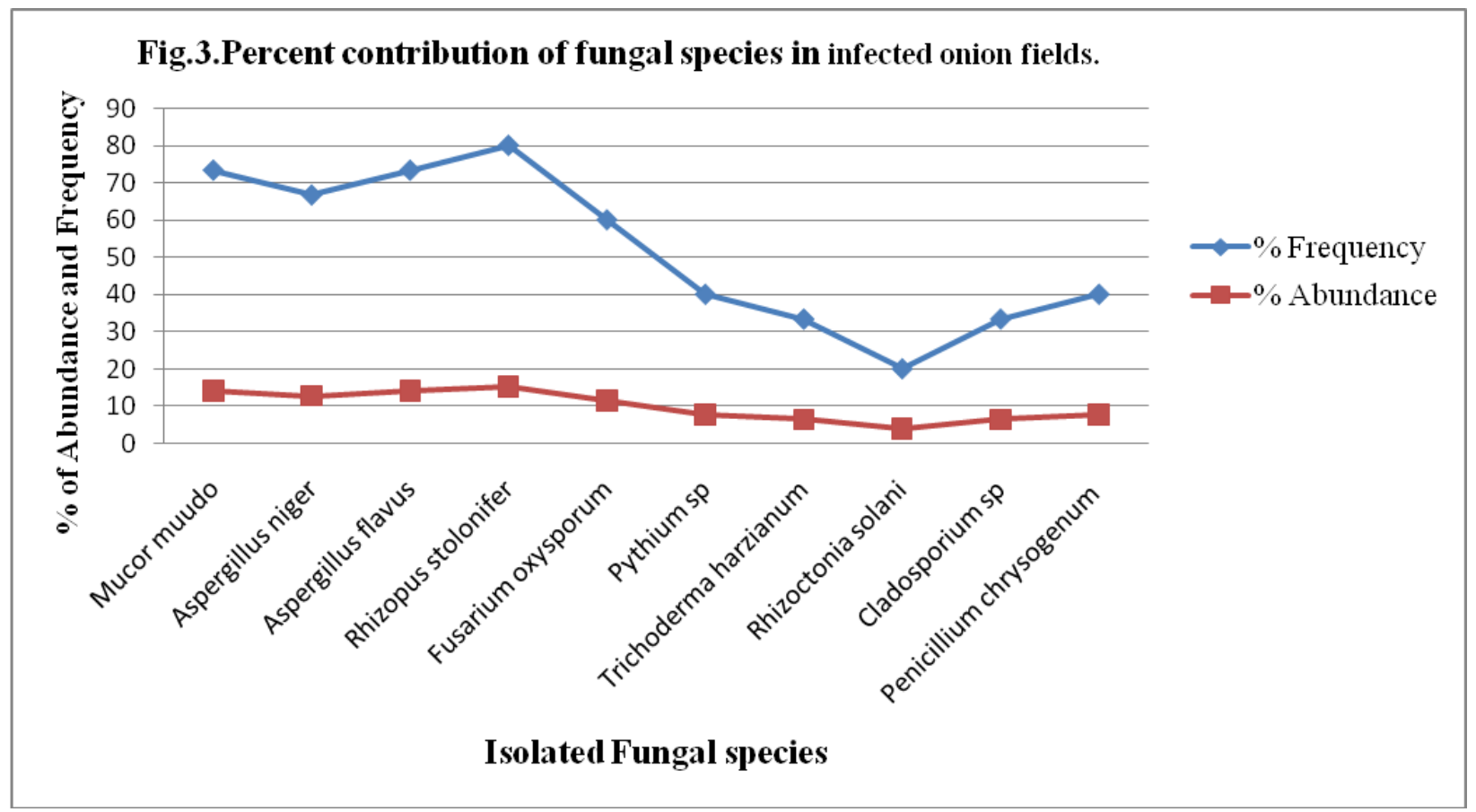

Ganorkarand Chinchmalatpure (2013) studied on soils with physical properties, chemical properties and micronutrients of soils have been done and the values of $\mathrm{pH}$ indicated that all samples of the soils are alkaline and all samples were containing moderate amounts of available micronutrients. Joel and Amajuoyi (2009) studied some selected physicochemical parameters and heavy metals in a drilling cutting dump site and test results indicated that some of the heavy metals like copper, iron and calcium showed a high level of contamination in most of the plots under the study area. Mahajan and Billore (2014) studied on the physicochemical parameters like $\mathrm{pH}$, specific conductivity, chloride, total alkalinity, calcium, magnesium nitrate, sulphate, phosphate sodium and potassium from July 2008 to June 2009 and fluctuation were observed in several parameters.(Vernon Paren (2010) reported that the salinity values above $2 \mathrm{dS} / \mathrm{m}$ begin to cause problems with salt sensitive plants, and values above $4 \mathrm{dS} / \mathrm{m}$ are problems for many garden and landscape plants.
The conservation of diversity of mycoflora in agricultural fields becomes very essential for the development of sustainable agriculture. The soil $\mathrm{pH}$, organic content and water are the main factors affecting the fungal population and diversity (Yu et al., 2007; Zhang et.al, 2001; Jha et al., 1992). Hackl et al (2000) reported the plant species growing on the soil also equally influence the population and species composition of the soil fungi. Soil fungi have significant impact on the several activities of soil ecosystem. Some studies on soil fungi of agricultural fields of Tamilnadu, Andhra Pradesh, Odisha and other remaining states of India enlightened the importance of soil mycoflora in agricultural fields (Prince and Prabakaran, 2012; Gaddeyya et al., 2012; Behera et al., 2012). It was reported that the density of fungal population occurred during the monsoon season when the soil moisture was significantly high (Deka and Mishra, 1984) and environmental factors such as $\mathrm{pH}$, moisture, temperature, organic carbon, organic, nitrogen play an important role in the distribution of mycoflora. Fungal diversity of 
any soil depends on a large number of factors of the soil such as $\mathrm{pH}$, organic content and moisture (Rangaswami and Bagyaraj, 1998; Alexander, 1977).

In conclusion, the physicochemical parameters are important to plant growth and status of microbiota, therefore the study concluded that the soil quality can be carried out by different parameters. Most of the parameters are quite higher or lower than acceptable limits. The saprobic fungi represent the largest proportion of fungal species in soil and they perform a crucial role in the decomposition. In conclusion, in the present study fifteen different onion field soil samples of four districts were studied for screening and detected of fungal diversity. Aspergillus, Penicillium and Mucor species were found dominant. It observed from finding that when more population of fungi shows less onion infection by Sclerotium cepivorum. Our finding determines the differences in fungal species composition of onion infected soils and management practices have greater potential to influence the soil fungal community in future.

\section{References}

Ainsworth, G.C., Sparrow, F.K. and Sussman, A.S. 1973. The fungi - An advanced treatise: A

Taxonomic review with keys. In: Ascomycetes and fungi Imperfecti. New York; Academic Press, 4(A): 621 pp.

Alexander, M.1977.Introduction to soil microbiology. 2nd edn. New York, NY: John Wiley \& Sons, Pp. 207.

Aneja,K.R. 2001.Experiments in Microbiology, Pant pathology and Biotechnology, Newage International Publishers. 4: 157-162.

Anonymous.2009. National Horticultural Research and Development
Foundation (NHRDF), NasikNewsletter, XXIX (4).

Arunachalam, K., Arunachalam, A., Tripathi, R. S. and Pandey H. N. 1997. Dynamics of microbial population during the aggradation phase of a selectively logged subtropical humid forest in north east India. Trop. Ecol. 38, 333-341.

Behera, B. C., Mishra R. R., Thatoi H. N. 2012. Diversity of soil fungi from mangroves of Mahanadi delta, Orissa, India, J. Microbiol. Biotech. Res., 2(3), 375-378.

Bissett, J, Parkinson, D.1979. Fungal community structure in some alpine soils. Can. J. Bot. 57:1630-1641.

Bray, R H and Kurtz, L. T. 1945. Determination of total, organic and available forms of phosphorus in soils, Soil Sci., 59:30-45.

Deka, H.K. and Mishra, R.R. 1984. Distribution of soil microflora in jhum fallows in NE India. Acta Botanica Indica, 12: 180-184.

Ellis, M.B. 1976.More dematiaceous Hyphomycetes. Common wealth mycological institute, Pub., Kew, Survey, England.

FAO.2012. Onion Production. Food and Agriculture Organization (FAO) of the United Nations, FAOSTAT., http:// faostat.fao.org.

Fawcett, R. and Caruana, S. 2001. Better soil better yields. In: A guidebook to improving soil organic matter and infiltration, CTIC West Lafayette, Indiana, pp. 1-20.

Gaddeyya, G., Shiny Niharika P., Bharathi, P., Ratna Kumar P.K.,2012.Isolation and identification of soil mycoflora in different crop fields at Salur Mandal. Adv. Appl. Sci. Res, 3(4): 2020-2026.

Girisham, S. 1986. Studies on mycotoxin producing fungi associated with pearl millet (Pennisetum americanum L.). 
Ph.D thesis, Kakatiya University, Warangal.

GOI. 2011, Methods Manual Soil Testing in India. Ministry of Agriculture Government of India, Pp. 1-215.

Hackl, E., Bachmann, G., BoltensternZechmeister, S. 2000. Soil microbial biomass and rhizosphere effects in natural forest stands, Phyton, 40, 8390.

Hanway, J. J. and Heidel, H. 1952. Soil analysis methods as used in Iowa state college soil testing laboratory. Iowa Agri, 57, 1-31.

Jackson, M.L 1967. Soil chemical analysis. Prentice Hall of India Pvt. Ltd. New Delhi, Pp. 36-82.

Jha, D.K., Sharma G.D., Mishra R.R. 1992. Ecology of soil micoflora and mycorrhizal symbionts in degraded forests at two altitudes, Biol.Fert.Soils, 12: $272-278$

Joel, O.F., Amajuyoyi, C.A. 2009. Determination of Selected Physicochemical Parameters and Heavy Metals in a Drilling Cutting Dump Site at Ezeogwu-Owaza, Nigeria, J Appl. Sci. Environ. Manage, 13(2):27-31.

Kennedy, N.M., D.E. Gleeson, J. Connolly and Clipson, N.J.W. 2005. Seasonal and management influences on bacterial community structure in an upland grassland soil. Ecol., 53:329337.

Kiran, G. Chaudhari.2013.Studies of the physicochemical parameters of soil samples. Advances in Applied Science Research, 4(6): 246-248.

Mahajan, S., Billore, D. 2014. Assessment of Physico- Chemical characteristics of the Soil of Nagchoon Pond Khandwa, MP, India. Res. J Chem Sci., 4(1):2630.

Mungikar, A M 1997.An Introduction to Biometry. Saraswati Printing Press,
Aurangabad, pp. 57-63.

Nagamani, A., I.K, Kunwar and Manoharachary, C. 2006. Hand book of soil fungi, I.K. International Pvt. Ltd,

Olsen, S.R, C.V. Cole, F. S. Watanabe and Dean, L. A. 1954. Estimation of available phosphorus in soils by extraction with sodium bicarbonate. USDA Circular No., 939.

Prince, L., Prabakaran, P. 2012. Studies on the Soil Mycoflora from the Sugarcane field in Thanjavur District, Tamilnadu, J. Microbiol., Biotech.Res, 2(1): 63-69.

Rangaswami, G. and Bagyaraj, D.J. 1998. Agricultural Microbiology. IInd edition published by Prentice Hall of India Pvt. Ltd. N. Delhi, p.422.

Rajesh, P Ganorkar, Chinchmalatpure, P.G. 2013. Physicochemical Assessment of Soil in Rajura Bazar in Amravati District of Maharashtra (India) International Journal of Chemical, Environmental and Pharmaceutical Research May- December.; 4(2\&3): 46-49.

Sahilemedhin, S and Bekele, T.2000. Procedures for soil and plant analysis. National soil research centre Ethiopian Agricultural Research Organization, Addis Ababa, Ethiopia,

Singh, K., J. Borana., and Srivastava.S.1999. Dynamics of Soil Microflora in Different Land Use Systems. Journal of Soil Biology and Ecology, Pp. 19.

Singh, B. 2001. Heavy metals in soils sources, chemical reactions and forms. In 'GeoEnviron Proceedings of the 2nd Australia and New Zealand Conference on Environmental Geotechnology, Newcastle, New South Wales' Eds D Smith, S Fityus and M Allman.; pp. 77-93.

Subbiah, B. V. and Asija, G. L.1956.A rapid procedure for determination of available nitrogen in soils, Curr.Sci, 
259-260.

Shamir, I. and Steinberger, I.2007. Vertical Distribution and Activity of Soil Microbial. Population in a Sandy Desert. Ecosystem. Micro. Ecol., 53: 340-347.

Trautmann, N. 1992. The Science and Engineering of Composting, Cornell Composting. Cornell University Press, Ithaca, New York.

Walkely, A. J., and Black, I. A. 1934. Estimation of soil organic carbon by the chromic acid titration method, Soil Sci., 37, 29-38.
Warcup, J.H. 1950. The soil plate methods for isolation of fungi from soil.Nature, 117 $-118$.

Yu, C., Lv, D.G, Qin, S.J., Du, G.D., Liu, G.C. 2007. Microbial flora in Cerasus sachalinensis rhizosphere, Chinese. $J$. Appl. Ecol, 18(10): 2277-2281.

Zhang, C.B., Jin, Z.X., Li, J.M. 2001. Diversity of bacterial physiological groups and microbial flora in the soil of eight forest types of Tiantai Mountain, Zhejiang, Biodiversity Sci., 9(4): 382-88.

\section{How to cite this article:}

Kumbhar, V.R., S.R. Mane, G.M. Birajdar, S.A. Bansode, C.S. Swami and Bhale, U.N. 2018. Physicochemical Characterization and Papulation Dynamics of Mycoflora in Infected Rhizosphere Soil of Onion White Rot caused by Sclerotium cepivorum. Int.J.Curr.Microbiol.App.Sci. 7(08): 3771-3780. doi: https://doi.org/10.20546/ijcmas.2018.708.384 